\title{
Human genetics and malaria resistance
}

\author{
Silvia N. Kariuki ${ }^{1} \cdot$ Thomas N. Williams $^{1,2}$ (D)
}

Received: 25 November 2019 / Accepted: 18 February 2020 / Published online: 4 March 2020

(c) The Author(s) 2020

\begin{abstract}
Malaria has been the pre-eminent cause of early mortality in many parts of the world throughout much of the last five thousand years and, as a result, it is the strongest force for selective pressure on the human genome yet described. Around one third of the variability in the risk of severe and complicated malaria is now explained by additive host genetic effects. Many individual variants have been identified that are associated with malaria protection, but the most important all relate to the structure or function of red blood cells. They include the classical polymorphisms that cause sickle cell trait, $\alpha$-thalassaemia, G6PD deficiency, and the major red cell blood group variants. More recently however, with improving technology and experimental design, others have been identified that include the Dantu blood group variant, polymorphisms in the red cell membrane protein $A T P 2 B 4$, and several variants related to the immune response. Characterising how these genes confer their effects could eventually inform novel therapeutic approaches to combat malaria. Nevertheless, all together, only a small proportion of the heritable component of malaria resistance can be explained by the variants described so far, underscoring its complex genetic architecture and the need for continued research.
\end{abstract}

\section{Introduction}

Malaria has been the biggest cause of childhood mortality globally for much of the last 5000 years. Although now coming under some degree of control, mortality remains high in many countries and worldwide there were an estimated 405,000 deaths from malaria in 2018 alone, with more than $90 \%$ of these deaths occurring in sub-Saharan Africa (WHO 2019). Historically, this pressure has resulted in the selection of a wide range of genetic variants that confer protection against malaria-specific death. This review aims to outline some of the more important protective genetic variants that have been identified so far, as summarized in the Table 1 . Understanding how these variants confer their protective effects has the potential to inform novel preventative and treatment approaches.

Silvia N. Kariuki

SNKariuki@kemri-wellcome.org

Thomas N. Williams

tom.n.williams@gmail.com; tom.williams@imperial.ac.uk

1 Department of Epidemiology, KEMRI-Wellcome Trust Research Programme, Kilifi, Kenya

2 Department of Medicine, Imperial College of Science and Technology, London, UK
Malaria can be caused by five different species of protozoan Plasmodium parasites: $P$. falciparum, $P$. vivax, $P$. malariae, $P$. ovale and $P$. knowlesi. P. falciparum and $P$. vivax are the most prevalent and result in the majority of deaths (Escalante et al. 1995; Singh et al. 2004; Martinsen et al. 2008; WHO 2019). The propagation of all malaria parasites involves both a sexual cycle in mosquitoes and an asexual cycle in humans, in which parasites first infect the liver before becoming established in red blood cells (RBCs). The clinically symptomatic blood-stage involves sequential rounds of parasite multiplication that incorporate invasion of merozoites into RBCs followed by their maturation into trophozoites then schizonts, which ultimately rupture from the RBC to release fresh merozoites which rapidly infect new RBCs (Fig. 1). The asexual cycle gives rise to an exponential multiplication of parasites in the blood and to the pathogenic features of malaria that are observed in the human host (Schellenberg et al. 1994; Rogier et al. 1999; Snow et al. 2005). The parasite is able to evade the host immune response by sequestering in the deep capillaries (Rowe et al. 1995, 2009; Williams et al. 2002; Butthep et al. 2006). There are multiple points in the parasite lifecycle that have impacted host genetic variation, but the majority of the malaria-protective variants described so far have various important impacts on the structure and function of the RBC (Fig. 1). 


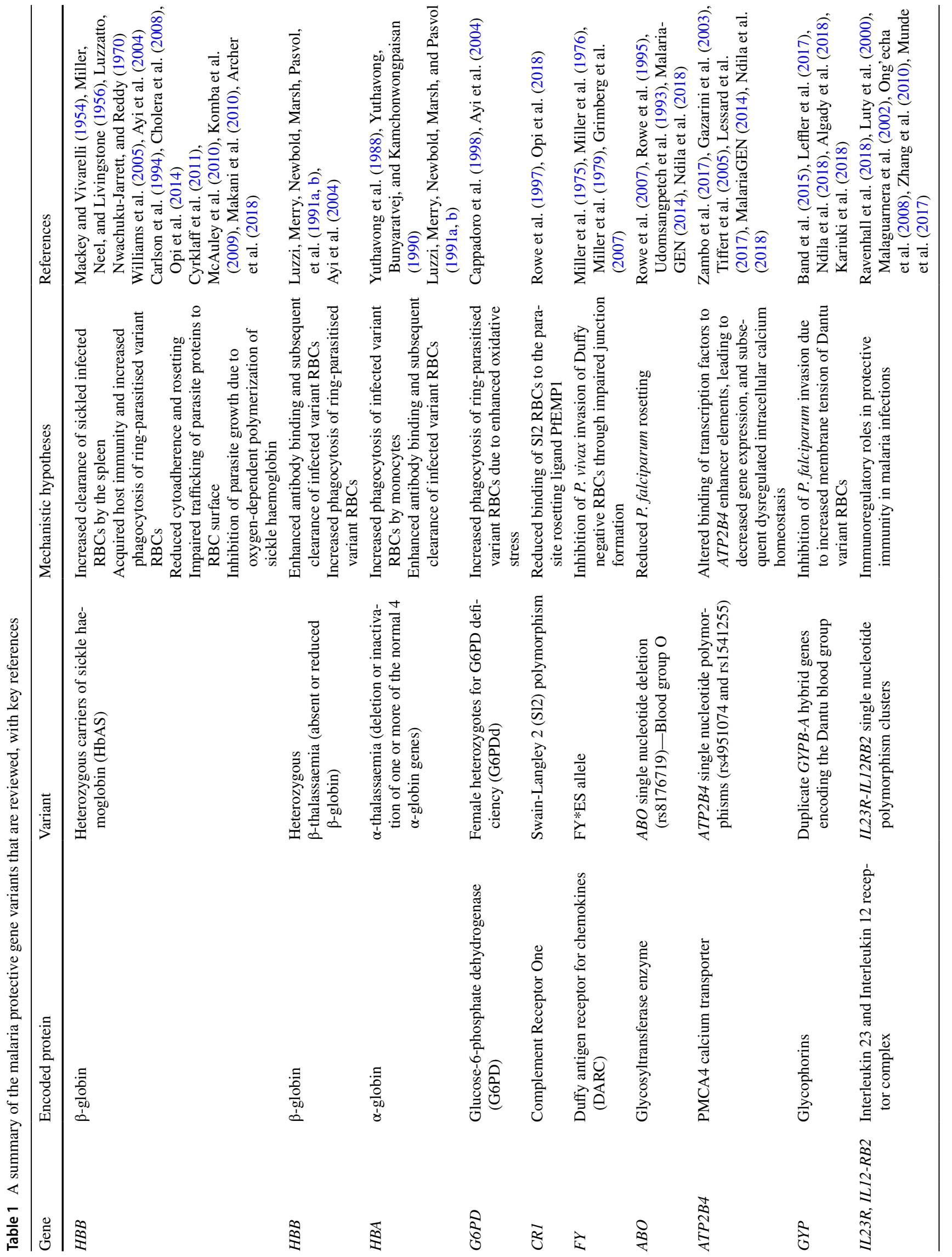




\section{The selective force of malaria on the human genome}

The "malaria hypothesis" was first proposed by JBS Haldane more than seventy years ago (Haldane 1949). He speculated that the reason why thalassaemia was common in the Mediterranean region was because it conferred a survival advantage against malaria. At around the same time, Allison (Allison 1954) and others were speculating that malaria selection might also have explained the high frequency of haemoglobin $\mathrm{S}(\mathrm{HbS})$ in malaria endemic areas. Both the thalassaemias and $\mathrm{HbS}$ are disorders of haemoglobin that are caused by various mutations in the $\alpha$ - and $\beta$-globin genes $(H B A$ and $H B B$ ). It took many years for the veracity of these hypotheses to be established beyond reasonable doubt, but it is now clear that the $\mathrm{HbS}$ variant confers the strongest protective effect against severe malaria that has yet been described, with an effect size of $>80 \%$ in heterozygous carriers (HbAS; sickle cell trait), while $\alpha$-thalassaemia confers a protective effect of approximately $40 \%$ in homozygotes (MalariaGEN 2014; Ndila et al. 2018). Other protective red blood cell (RBC) polymorphisms have also been shown to occur at their highest frequencies in malaria endemic populations, including glucose-6-phosphatase (G6PD) deficiency, the $\mathrm{O}$ blood group, and variants of the gene for complement receptor 1 (CRI) (Kwiatkowski 2005; Williams 2016; Rowe et al. 1997; Opi et al. 2018).

One of the first and most conclusive examples of malaria effecting a strong selective pressure on the human genome is the Duffy antigen receptor for chemokines (DARC), which is expressed on red blood cell membranes and has roles as both a chemokine receptor (Horuk et al. 1993; Pogo and Chaudhuri 1995; Hadley and Peiper 1997) and an invasion receptor for Plasmodium vivax merozoites (Miller et al. 1975, 1976; Wertheimer and Barnwell 1989; Adams et al. 1990; Chitnis and Miller 1994; Grimberg et al. 2007). DARC is encoded by the Duffy blood group $F Y$ gene, that occurs in the form of three common alleles with starkly differing global allele frequency distributions: $F Y^{*} A, F Y^{*} B$ and the "erythrocyte silent" $F Y^{*} E S$. The $F Y^{*} E S$ allele, which results in the absence of the Duffy antigen, is found at frequencies nearing fixation in sub-Saharan Africa but is virtually absent in nonAfrican populations (Hamblin and Di Rienzo 2000; Howes et al. 2011). The allele frequency difference of the $F Y^{*} E S$ allele across populations is the largest difference observed in the human genome to date (Cavalli-Sforza, Menozzi, and Piazza 1994), a strong indicator of positive natural selection (Hamblin and Di Rienzo 2000). These and similar data suggest that malaria has been responsible for exerting the strongest selective pressure on the human genome that has so far been described (Flint et al. 1998; Tishkoff and Williams 2002).

\section{Heritability of malaria}

The extent to which variation in the incidence of malaria is attributed to host genetic factors has been investigated in a number of studies. Using pedigree-based variance component analysis, studies conducted in Sri Lanka (Mackinnon et al. 2000), Kenya (Mackinnon et al. 2005), Senegal (Sakuntabhai et al. 2008) and Thailand (Phimpraphi et al. 2008) have established that additive genetic factors explain approximately one quarter of the total variation in the incidence of uncomplicated $P$. falciparum malaria and more than one third of the variation in severe and complicated disease. However, only $2 \%$ of this variance appears to be explained by $\mathrm{HbS}$ and $\alpha$-thalassaemia together, two of the most important polymorphisms discovered so far in terms of their frequencies and effect sizes (Mackinnon et al. 2005). This indicates that the genetic architecture of malaria susceptibility is much more complex than is currently understood and that "missing heritability" might yet be explained by polygenetic or epigenetic effects, or by gene-gene and gene-environment interactions (Manolio et al. 2009).

\section{Protective loci identified by linkage and genomic epidemiology}

Malaria associated genes have been identified through numerous approaches including family-based studies that have linked broad chromosomal regions to the risk of malaria parasite carriage (Garcia et al. 1998; Rihet et al. 1998; Flori et al. 2003a, b; Timmann et al. 2007). Such early studies were, however, limited in their ability to fine-map the specific gene variants underlying the broad chromosomal linkage signals. More recently, genomic epidemiology approaches such as case-control and cohort studies have focused on characterising the allele frequency distributions, effect sizes and directions of effect of various candidates including $\mathrm{HbS}, \alpha$-thalassaemia, G6PD deficiency, and the ABO blood group locus (Allison 1954; Bienzle et al. 1972; Ruwende et al. 1995; Wambua et al. 2006; MalariaGEN 2014). While many have now been shown to be associated with significant effects, recent studies suggest that these known candidate genes only explain a small fraction of the heritability of malaria and that there could be many other genetic variants that are unaccounted for by the single-gene study approach (Mackinnon et al. 2005; Verra, Mangano, and Modiano 2009; Damena et al. 2019). 


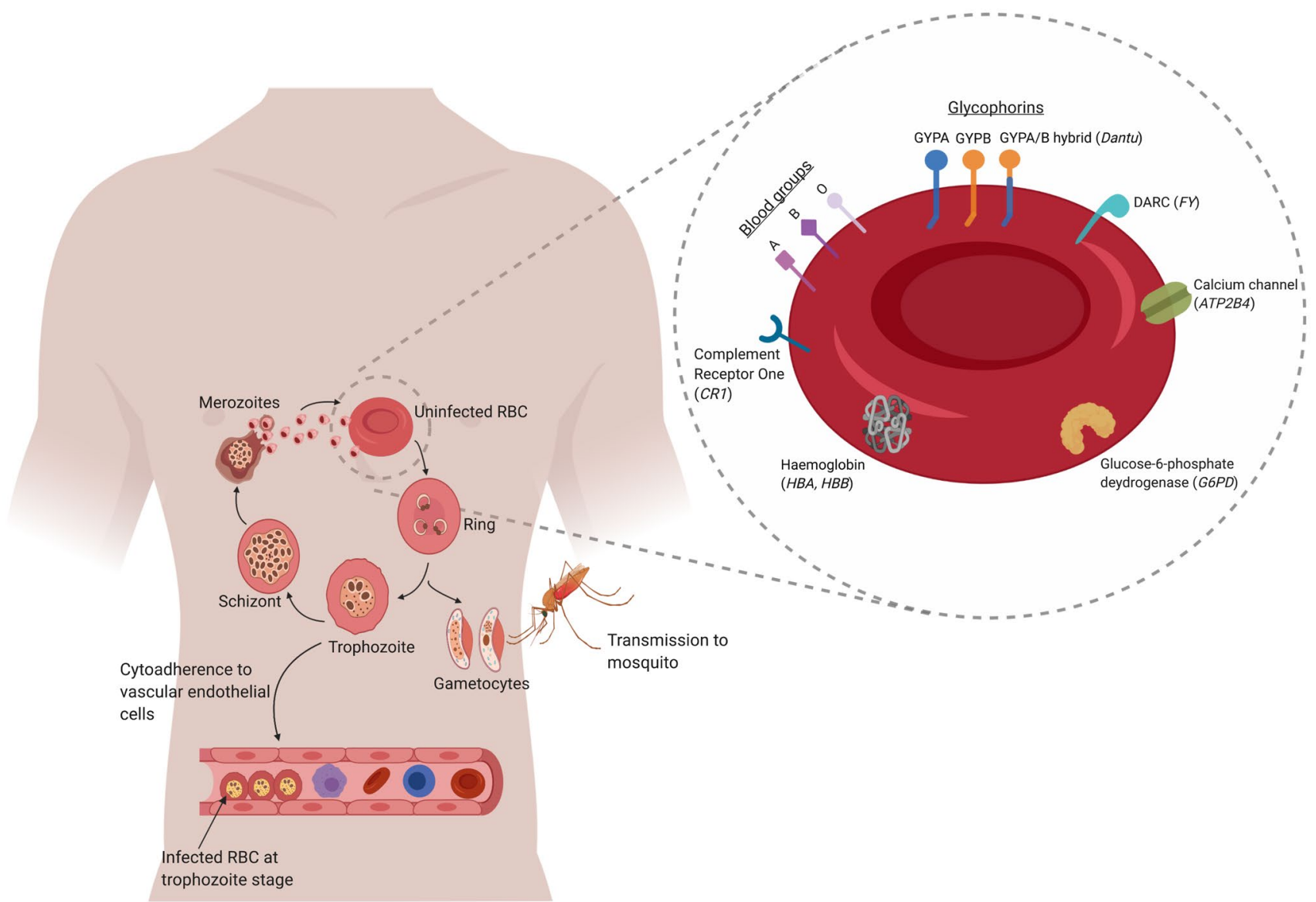

Fig. 1 The blood-stage of the $P$. falciparum life cycle in the human host. Inset: illustration of the malaria-protective variants that have important roles in the red blood cell (RBC). Image made using @BioRender (https://biorender.com)

\section{Novel resistance loci identified by genome-wide association studies}

Recent genome-wide association studies (GWAS) in malaria endemic populations have confirmed many of the classical malaria associated genes (MalariaGEN 2014, 2019) and enabled the identification of additional novel associations (Jallow et al. 2009; Timmann et al. 2012; Band et al. 2015; Ravenhall et al. 2018; MalariaGEN 2019). There have been various challenges with performing GWAS in African populations (Teo et al. 2010; Damena et al. 2019). Africans have high levels of genomic diversity due to their long ancestral history and, compared to non-African populations, their genomes are characterized by shorter linkage disequilibrium blocks between loci (Tishkoff and Williams 2002; Conrad et al. 2006; Campbell and Tishkoff 2008; Jakobsson et al. 2008; Tishkoff et al. 2009). The genotyping platforms that were used in early GWAS studies therefore had low tagging efficiency in these populations and resulted in relatively weak associations, even at some of the best known malaria associated loci such as HbS (Jallow et al. 2009).
Furthermore, few analyses have considered interactions between genes and even fewer have incorporated genomic data from the parasites or vectors that might be relevant to patient outcomes (Damena et al. 2019). While such approaches are now becoming increasingly feasible from a computational perspective, they are currently limited by the availability of such rich phenotypic data-an aspiration for future studies. In the meantime, the performance of humanonly GWAS studies have been substantially improved by the imputation of missing variants through the inclusion in reference panels of more diverse African populations (Band et al. 2013; Gurdasani et al. 2015, 2019; MalariaGEN 2019), the use of customised representative genotyping platforms that better capture the genomic diversity of African populations (Gurdasani et al. 2015, 2019; Johnston et al. 2017) and the additional deep sequencing of target loci (Jallow et al. 2009; Band et al. 2015; Leffler et al. 2017). In a recent study, the inclusion of a denser reference panel in combination with sequence data from Phase 3 of the 1000 Genomes Project (Auton et al. 2015) significantly improved the quality of variant calling in one severe malaria GWAS, 
including the identification of copy number variants that had not been detected in an earlier analysis (Leffler et al. 2017). Such improvements have recently led to the identification of new associations, including variants in $A T P 2 B 4$ which encodes the major calcium transporter in RBCs, PMCA4, and confers a 40\% protective effect (Timmann et al. 2012; Band et al. 2015; MalariaGEN 2019). The ATP2B4 variants lead to reduced expression of the PMCA4 protein, possibly due to altered binding of transcription factors that regulate PMCA4 expression (Zambo et al. 2017; MalariaGEN 2019). This reduced PMCA4 expression could lead to alterations in intracellular calcium homeostasis and affect the development of parasites during their intra-erythrocytic lifecycle (Gazarini et al. 2003; Tiffert et al. 2005). More functional studies are required to elucidate the exact protective mechanisms.

A second recently described novel malaria resistance gene involves a complex structural rearrangement in the glycophorin gene cluster that results in the gain of two GYPB-A hybrid genes to encode the Dantu blood group antigen (Leffler et al. 2017). Glycophorins are sialoglycoproteins that are abundantly expressed on the surface of RBCs and that bear the antigenic determinants of the MNS blood groups (Blumenfeld and Huang 1995, 1997). This locus provides an exciting potential therapeutic target for $P$. falciparum therapies because, akin to the story of $P$. vivax malaria, the glycophorins have been shown to act as invasion ligands for the Duffy-Binding-Like (DBL) domains of a range of P. falciparum merozoite proteins (Sim et al. 1994; Tolia et al. 2005; Mayer et al. 2001, 2002, 2004, 2006, 2009). In homozygotes, Dantu confers a strongly protective effect size of $74 \%$ against all forms of severe falciparum malaria (Band et al. 2015, Leffler et al. 2017, Ndila et al. 2018, MalariaGEN 2019). Curiously, this polymorphism is found at highest frequencies in East Africa, specifically in the coastal region of Kilifi, and is rare or absent in other malaria endemic regions. One possible explanation is that positive selection for the Dantu polymorphism by malaria might historically have been balanced by increased mortality from other diseases. Interestingly, features of ancient balancing selection are seen at this locus (Leffler et al. 2013; Band et al. 2015), underscoring the fact that malaria could be one of a number of opposing evolutionary driving forces acting on the glycophorin region, a question that is currently being addressed in ongoing studies.

In a recent GWAS conducted in north-east Tanzania, novel variants were identified in the immune genes $I L-23 R$ and $I L-12 R B 2$ which were specifically found to be associated with protection against severe malaria anaemia (Ravenhall et al. 2018). These genes encode vital pro-inflammatory cytokine receptors which have important immunoregulatory roles in protective immunity against malaria infections (Luty et al. 2000; Malaguarnera et al. 2002; Ong'echa et al. 2008; Zhang et al. 2010; Munde et al. 2017). In the same cohort, signals of recent positive selection were also found at several loci within the MHC region, immune-related genes that could potentially inform malaria vaccine development.

\section{Functional validation of malaria-protective genes}

Beyond identifying malaria-protective gene variants, investigations into the mechanisms through which these variants confer their protective effects are critical to informing novel approaches to intervention. Functional studies have led to the elucidation of key steps in the molecular processes involved in parasite invasion of host RBCs, with the seminal example of the $F Y$ gene that encodes DARC (formerly known as the Duffy blood group system of antigens). This discovery led to further functional studies that identified the $P$. vivax Duffy-binding protein $(P v \mathrm{DBP})$ that is crucial for RBC invasion (Miller et al. 1979; Haynes et al. 1988; Wertheimer and Barnwell 1989; Chitnis and Miller 1994), which is now undergoing clinical trials as a vaccine candidate (Chitnis and Sharma 2008; Mueller, Shakri, and Chitnis 2015). Cases of $P$. vivax infection in $F Y^{*} E S$ individuals have more recently been reported (Ryan et al. 2006; Menard et al. 2010; Ngassa Mbenda and Das 2014; Lo et al. 2015; Abdelraheem et al. 2016; Niangaly et al. 2017). Functional work leading to the discovery of transferrin receptor 1 (TfR1) as an important alternative receptor for $P$. vivax recognition and invasion of RBCs could explain these cases (Gruszczyk et al. 2018). TfR 1 is a receptor for the $P$. vivax reticulocyte binding protein $2 b$ (PvRBP2b) and as such it offers a potential alternative vaccine target.

In the case of the most strongly protective variant against P. falciparum, HbAS, several mechanisms of protection have been proposed, including sickling of the infected RBCs (Mackey and Vivarelli 1954; Miller, Neel, and Livingstone 1956), leading to increased clearance by the spleen (Luzzatto, Nwachuku-Jarrett, and Reddy 1970), impaired haemoglobin digestion (Pasvol, Weatherall, and Wilson 1978; Pasvol 1980; Friedman 1978), and acquired host immunity (Williams et al. 2005). More recently, Cyrklaff et al. showed that the actin cytoskeleton network that directs RBC trafficking of parasite encoded proteins, such as the P. falciparum erythrocyte membrane protein-1 (PfEMP1), was impaired in HbAS RBCs (Cyrklaff et al. 2011). Impaired trafficking of parasite proteins to the surface of the RBC could explain the observation that cytoadherence of parasitised RBCs to the vascular endothelium, and binding of parasitised RBCs to uninfected RBCs to form rosettes, are both significantly reduced in HbAS RBCs (Carlson et al. 1994; Cholera et al. 2008; Opi et al. 2014). The latter observation is akin to that postulated as the protective mechanism for blood group O (Rowe et al. 1995, 2007; Udomsangpetch et al. 1993). 
Furthermore, impaired parasite growth and development in HbAS RBCs has also been reported (McAuley et al. 2010; Komba et al. 2009; Makani et al. 2010), with one recent study demonstrating that oxygen-dependent polymerization of $\mathrm{HbS}$ is responsible for $P$. falciparum growth inhibition (Archer et al. 2018). Finally, immune-mediated protective mechanisms have also been postulated for $\mathrm{HbAS}$, as well as $\alpha$ - and $\beta$-thalassaemias, and G6PD deficiency. These include enhanced antibody binding and phagocytosis of infected variant RBCs, possibly due to oxidative damage of the RBC membrane (Yuthavong et al. 1988,1990; Luzzi et al. 1991a, b; Ayi et al. 2004; Cappadoro et al. 1998).

Technological advances have further aided the functional validation efforts for newly identified malaria-protective variants. Lessard et al. investigated the $A T P 2 B 4$ locus in detail using transcriptomics, epigenomics, and gene-editing, and found that the ATP2B 4 GWAS SNPs mapped to enhancer elements that regulated $A T P 2 B 4$ gene expression and subsequent intracellular calcium homeostasis (Lessard et al. 2017). Functional annotation of the malaria-protective ATP2B4 SNPs in the recent GWAS carried out by the Malaria Genomic Epidemiology Network also found that these SNPs regulate ATP2B4 gene expression by disrupting the promoter upstream of the gene's transcription start site (MalariaGEN 2019). Similarly, since the protective association of Dantu was first discovered, the molecular basis of the Dantu blood group antigen has been further resolved through whole genome sequencing (Leffler et al. 2017). It is now clear that Dantu consists of duplicate GYPB-A hybrid genes whose encoded protein contains the extracellular domain of glycophorin B and the transmembrane and intracellular domains of glycophorin A (Leffler et al. 2017). This molecular structure was further validated by fluorescent in situ hybridization using single-molecule DNA fibres (fibreFISH) in lymphoblastoid cell lines (Algady et al. 2018). A recent study elucidated the inhibitory impact of Dantu on parasite invasion and, further, demonstrated that this protective effect was mediated by increased membrane tension (Kariuki et al. 2018). These functional studies have provided crucial insights into the biology of host-parasite interactions, and this biological knowledge is critical in developing novel intervention approaches for combating malaria.

\section{Conclusion}

Malaria is the first, and arguably still remains the best, example of the impact that infectious diseases can have on the human genome. While numerous genes have now been identified that are strongly associated with the risk of different forms of malaria, it is those relating to the structure or function of RBCs for which the data are most compelling. This is entirely consistent with the fact that for all but a brief period during the incubation phase, the biological success of malaria parasites in humans is entirely dependent on their ability to invade, grow, and survive within RBCs. While some, including $\mathrm{HbAS}$, the thalassaemias and G6PD deficiency, have been selected to extreme frequencies because of their malaria-protective effects, in many cases the mechanisms are either too poorly understood or too complex to suggest plausible approaches to the development of new treatments (Lelliott et al. 2015; Goheen, Campino, and Cerami 2017). Perhaps the most promising in this regard are polymorphisms in genes that are integral to the pathways by which parasites gain entry to red blood cells. Of particular current interest is the Dantu mutation in the glycophorin molecules that are important ligands in the parasiteinvasion process. Remarkably however, the mechanism by which Dantu results in reduced invasion does not appear to be through a specific impact on receptor-ligand interactions but through a more non-specific mechanism whereby Dantu results in increased red cell tension. While further work is necessary, it is possible that drugs or small molecules could be developed with a view to inducing increased tension in non-Dantu subjects and thus providing therapeutic benefit in both treatment and prevention.

Acknowledgements SNK is supported by the Wellcome Trust-funded Initiative to Develop African Research Leaders (IDeAL) early-career postdoctoral fellowship and TNW is funded through Fellowships awarded by the Wellcome Trust (091758 and 202800). This paper is published with permission from the Director of KEMRI.

\section{Compliance with ethical standards}

Conflict of interest The authors of this article have no conflicts to declare.

Open Access This article is licensed under a Creative Commons Attribution 4.0 International License, which permits use, sharing, adaptation, distribution and reproduction in any medium or format, as long as you give appropriate credit to the original author(s) and the source, provide a link to the Creative Commons licence, and indicate if changes were made. The images or other third party material in this article are included in the article's Creative Commons licence, unless indicated otherwise in a credit line to the material. If material is not included in the article's Creative Commons licence and your intended use is not permitted by statutory regulation or exceeds the permitted use, you will need to obtain permission directly from the copyright holder. To view a copy of this licence, visit http://creativecommons.org/licenses/by/4.0/.

\section{References}

Abdelraheem MH, Albsheer MM, Mohamed HS, Amin M, Hamid MMA (2016) Transmission of Plasmodium vivax in Duffy-negative individuals in central Sudan. Trans R Soc Trop Med Hyg 110(4):258-260. https://doi.org/10.1093/trstmh/trw014

Adams JH, Hudson DE, Torii M, Ward GE, Wellems TE, Aikawa M, Miller LH (1990) The Duffy receptor family of Plasmodium knowlesi is located within the micronemes of invasive malaria 
merozoites. Cell 63(1):141-153. https://doi.org/10.1016/00928674(90)90295-p

Algady W, Louzada S, Carpenter D, Brajer P, Farnert A, Rooth I, Ngasala B, Yang F, Shaw MA, Hollox EJ (2018) The Malariaprotective human glycophorin structural variant DUP4 shows somatic mosaicism and association with hemoglobin levels. Am J Hum Genet 103(5):769-776. https://doi.org/10.1016/j. ajhg.2018.10.008

Allison AC (1954) Protection afforded by sickle-cell trait against subtertian malarial infection. Br Med J 1(4857):290-294. https://doi. org/10.1136/bmj.1.4857.290

Archer NM, Petersen N, Clark MA, Buckee CO, Childs LM, Duraisingh MT (2018) Resistance to Plasmodium falciparum in sickle cell trait erythrocytes is driven by oxygen-dependent growth inhibition. Proc Natl Acad Sci USA 115(28):7350-7355. https://doi. org/10.1073/pnas. 1804388115

Auton A, Brooks LD, Durbin RM, Garrison EP, Kang HM, Korbel JO, Marchini JL, McCarthy S, McVean GA, Abecasis GR (2015) A global reference for human genetic variation. Nature 526(7571):68-74. https://doi.org/10.1038/nature15393

Ayi K, Turrini F, Piga A, Arese P (2004) Enhanced phagocytosis of ring-parasitized mutant erythrocytes: a common mechanism that may explain protection against falciparum malaria in sickle trait and beta-thalassemia trait. Blood 104(10):3364-3371. https:// doi.org/10.1182/blood-2003-11-3820

Band G, Le QS, Jostins L, Pirinen M, Kivinen K, Jallow M, SisayJoof F, Bojang K, Pinder M, Sirugo G, Conway DJ, Nyirongo V, Kachala D, Molyneux M, Taylor T, Ndila C, Peshu N, Marsh K, Williams TN, Alcock D, Andrews R, Edkins S, Gray E, Hubbart C, Jeffreys A, Rowlands K, Schuldt K, Clark TG, Small KS, Teo YY, Kwiatkowski DP, Rockett KA, Barrett JC, Spencer CC (2013) Imputation-based meta-analysis of severe malaria in three African populations. PLoS Genet 9(5):e1003509. https:// doi.org/10.1371/journal.pgen.1003509

Band G, Rockett KA, Spencer CC, Kwiatkowski DP (2015) A novel locus of resistance to severe malaria in a region of ancient balancing selection. Nature 526(7572):253-257. https://doi. org/10.1038/nature 15390

Bienzle U, Ayeni O, Lucas AO, Luzzatto L (1972) Glucose-6-phosphate dehydrogenase and malaria. Greater resistance of females heterozygous for enzyme deficiency and of males with non-deficient variant. Lancet 1(7742):107-110. https://doi.org/10.1016/ s0140-6736(72)90676-9

Blumenfeld OO, Huang CH (1995) Molecular genetics of the glycophorin gene family, the antigens for MNSs blood groups: multiple gene rearrangements and modulation of splice site usage result in extensive diversification. Hum Mutat 6(3):199-209. https://doi.org/10.1002/humu.1380060302

Blumenfeld OO, Huang CH (1997) Molecular genetics of glycophorin MNS variants. Transfus Clin Biol 4(4):357-365

Butthep P, Wanram S, Pattanapanyasat K, Vattanaviboon P, Fucharoen S, Wilairat P (2006) Cytoadherence between endothelial cells and $\mathrm{P}$. falciparum infected and noninfected normal and thalassemic red blood cells. Cytometry B Clin Cytom 70(6):432-442. https://doi.org/10.1002/cyto.b.20141

Campbell MC, Tishkoff SA (2008) African genetic diversity: implications for human demographic history, modern human origins, and complex disease mapping. Annu Rev Genomics Hum Genet 9:403-433. https://doi.org/10.1146/annurev.genom.9.08130 7.164258

Cappadoro M, Giribaldi G, O’Brien E, Turrini F, Mannu F, Ulliers D, Simula G, Luzzatto L, Arese P (1998) Early phagocytosis of glucose-6-phosphate dehydrogenase (G6PD)-deficient erythrocytes parasitized by Plasmodium falciparum may explain malaria protection in G6PD deficiency. Blood 92(7):2527-2534
Carlson J, Nash GB, Gabutti V, Al-Yaman F, Wahlgren M (1994) Natural protection against severe Plasmodium falciparum malaria due to impaired rosette formation. Blood 84(11):3909-3914

Cavalli-Sforza L, Menozzi P, Piazza A (1994) The history and geography of human genes. Princeton University Press, Princeton

Chitnis CE, Miller LH (1994) Identification of the erythrocyte binding domains of Plasmodium vivax and Plasmodium knowlesi proteins involved in erythrocyte invasion. J Exp Med 180(2):497-506. https://doi.org/10.1084/jem.180.2.497

Chitnis CE, Sharma A (2008) Targeting the Plasmodium vivax Duffybinding protein. Trends Parasitol 24(1):29-34. https://doi. org/10.1016/j.pt.2007.10.004

Cholera R, Brittain NJ, Gillrie MR, Lopera-Mesa TM, Diakite SA, Arie T, Krause MA, Guindo A, Tubman A, Fujioka H, Diallo DA, Doumbo OK, Ho M, Wellems TE, Fairhurst RM (2008) Impaired cytoadherence of Plasmodium falciparum-infected erythrocytes containing sickle hemoglobin. Proc Natl Acad Sci USA 105(3):991-996

Conrad DF, Jakobsson M, Coop G, Wen X, Wall JD, Rosenberg NA, Pritchard JK (2006) A worldwide survey of haplotype variation and linkage disequilibrium in the human genome. Nat Genet 38(11):1251-1260. https://doi.org/10.1038/ng1911

Cyrklaff M, Sanchez CP, Kilian N, Bisseye C, Simpore J, Frischknecht F, Lanzer M (2011) Hemoglobins S and C interfere with actin remodeling in Plasmodium falciparum-infected erythrocytes. Science 334(6060):1283-1286. https://doi.org/10.1126/scien ce. 1213775

Damena D, Denis A, Golassa L, Chimusa ER (2019) Genome-wide association studies of severe $P$. falciparum malaria susceptibility: progress, pitfalls and prospects. BMC Med Genomics 12(1):120. https://doi.org/10.1186/s12920-019-0564-x

Escalante AA, Barrio E, Ayala FJ (1995) Evolutionary origin of human and primate malarias: evidence from the circumsporozoite protein gene. Mol Biol Evol 12(4):616-626. https://doi.org/10.1093/ oxfordjournals.molbev.a040241

Flint J, Harding RM, Boyce AJ, Clegg JB (1998) The population genetics of the haemoglobinopathies. Baillieres Clin Haematol 11(1): $1-51$

Flori L, Kumulungui B, Aucan C, Esnault C, Traore AS, Fumoux F, Rihet P (2003a) Linkage and association between Plasmodium falciparum blood infection levels and chromosome 5q31q33. Genes Immun 4(4):265-268. https://doi.org/10.1038/ sj.gene. 6363960

Flori L, Sawadogo S, Esnault C, Delahaye NF, Fumoux F, Rihet P (2003b) Linkage of mild malaria to the major histocompatibility complex in families living in Burkina Faso. Hum Mol Genet 12(4):375-378

Friedman MJ (1978) Erythrocytic mechanism of sickle cell resistance to malaria. Proc Natl Acad Sci 75(4):1994-1997. https://doi. org/10.1073/pnas.75.4.1994

Garcia A, Marquet S, Bucheton B, Hillaire D, Cot M, Fievet N, Dessein AJ, Abel L (1998) Linkage analysis of blood Plasmodium falciparum levels: interest of the 5q31-q33 chromosome region. Am J Trop Med Hyg 58(6):705-709

Gazarini ML, Thomas AP, Pozzan T, Garcia CR (2003) Calcium signaling in a low calcium environment: how the intracellular malaria parasite solves the problem. J Cell Biol 161(1):103-110. https:// doi.org/10.1083/jcb.200212130

Goheen MM, Campino S, Cerami C (2017) The role of the red blood cell in host defence against falciparum malaria: an expanding repertoire of evolutionary alterations. Br J Haematol 179(4):543556. https://doi.org/10.1111/bjh.14886

Grimberg BT, Udomsangpetch R, Xainli J, McHenry A, Panichakul T, Sattabongkot J, Cui L, Bockarie M, Chitnis C, Adams J, Zimmerman PA, King CL (2007) Plasmodium vivax invasion of human erythrocytes inhibited by antibodies directed against the Duffy 
binding protein. Plos Med 4(12):e337. https://doi.org/10.1371/ journal.pmed.0040337

Gruszczyk J, Kanjee U, Chan LJ, Menant S, Malleret B, Lim NTY, Schmidt CQ, Mok YF, Lin KM, Pearson RD, Rangel G, Smith BJ, Call MJ, Weekes MP, Griffin MDW, Murphy JM, Abraham J, Sriprawat K, Menezes MJ, Ferreira MU, Russell B, Renia L, Duraisingh MT, Tham WH (2018) Transferrin receptor 1 is a reticulocyte-specific receptor for Plasmodium vivax. Science 359(6371):48-55. https://doi.org/10.1126/science.aan1078

Gurdasani D, Carstensen T, Fatumo S, Chen G, Franklin CS, PradoMartinez J, Bouman H, Abascal F, Haber M, Tachmazidou I, Mathieson I, Ekoru K, DeGorter MK, Nsubuga RN, Finan C, Wheeler E, Chen L, Cooper DN, Schiffels S, Chen Y, Ritchie GRS, Pollard MO, Fortune MD, Mentzer AJ, Garrison E, Bergstrom A, Hatzikotoulas K, Adeyemo A, Doumatey A, Elding H, Wain LV, Ehret G, Auer PL, Kooperberg CL, Reiner AP, Franceschini N, Maher D, Montgomery SB, Kadie C, Widmer C, Xue Y, Seeley J, Asiki G, Kamali A, Young EH, Pomilla C, Soranzo N, Zeggini E, Pirie F, Morris AP, Heckerman D, Tyler-Smith C, Motala AA, Rotimi C, Kaleebu P, Barroso I, Sandhu MS (2019) Uganda genome resource enables insights into population history and genomic discovery in Africa. Cell 179(4):984-1002. e36. https://doi.org/10.1016/j.cell.2019.10.004

Gurdasani D, Carstensen T, Tekola-Ayele F, Pagani L, Tachmazidou I, Hatzikotoulas K, Karthikeyan S, Iles L, Pollard MO, Choudhury A, Ritchie GR, Xue Y, Asimit J, Nsubuga RN, Young EH, Pomilla C, Kivinen K, Rockett K, Kamali A, Doumatey AP, Asiki G, Seeley J, Sisay-Joof F, Jallow M, Tollman S, Mekonnen E, Ekong R, Oljira T, Bradman N, Bojang K, Ramsay M, Adeyemo A, Bekele E, Motala A, Norris SA, Pirie F, Kaleebu P, Kwiatkowski D, Tyler-Smith C, Rotimi C, Zeggini E, Sandhu MS (2015) The African Genome Variation Project shapes medical genetics in Africa. Nature 517(7534):327-332. https://doi. org/10.1038/nature13997

Hadley TJ, Peiper SC (1997) From malaria to chemokine receptor: the emerging physiologic role of the Duffy blood group antigen. Blood 89(9):3077-3091

Haldane JBS (1949) Disease and evolution. Ric Sci Suppl 19:3-10

Hamblin MT, Di Rienzo A (2000) Detection of the signature of natural selection in humans: evidence from the Duffy blood group locus. Am J Hum Genet 66(5):1669-1679

Haynes JD, Dalton JP, Klotz FW, McGinniss MH, Hadley TJ, Hudson DE, Miller LH (1988) Receptor-like specificity of a Plasmodium knowlesi malarial protein that binds to Duffy antigen ligands on erythrocytes. J Exp Med 167(6):1873-1881. https:// doi.org/10.1084/jem.167.6.1873

Horuk R, Chitnis CE, Darbonne WC, Colby TJ, Rybicki A, Hadley TJ, Miller LH (1993) A receptor for the malarial parasite Plasmodium vivax: the erythrocyte chemokine receptor. Science 261(5125):1182-1184. https://doi.org/10.1126/science.7689250

Howes RE, Patil AP, Piel FB, Nyangiri OA, Kabaria CW, Gething PW, Zimmerman PA, Barnadas C, Beall CM, Gebremedhin A, Menard D, Williams TN, Weatherall DJ, Hay SI (2011) The global distribution of the Duffy blood group. Nat Commun 2:266. https://doi.org/10.1038/ncomms1265

Jakobsson M, Scholz SW, Scheet P, Gibbs JR, VanLiere JM, Fung HC, Szpiech ZA, Degnan JH, Wang K, Guerreiro R, Bras JM, Schymick JC, Hernandez DG, Traynor BJ, Simon-Sanchez J, Matarin M, Britton A, van de Leemput J, Rafferty I, Bucan M, Cann HM, Hardy JA, Rosenberg NA, Singleton AB (2008) Genotype, haplotype and copy-number variation in worldwide human populations. Nature 451(7181):998-1003. https://doi. org/10.1038/nature06742

Jallow M, Teo YY, Small KS, Rockett KA, Deloukas P, Clark TG, Kivinen K, Bojang KA, Conway DJ, Pinder M, Sirugo G, SisayJoof F, Usen S, Auburn S, Bumpstead SJ, Campino S, Coffey A,
Dunham A, Fry AE, Green A, Gwilliam R, Hunt SE, Inouye M, Jeffreys AE, Mendy A, Palotie A, Potter S, Ragoussis J, Rogers J, Rowlands K, Somaskantharajah E, Whittaker P, Widden C, Donnelly P, Howie B, Marchini J, Morris A, SanJoaquin M, Achidi EA, Agbenyega T, Allen A, Amodu O, Corran P, Djimde A, Dolo A, Doumbo OK, Drakeley C, Dunstan S, Evans J, Farrar J, Fernando D, Hien TT, Horstmann RD, Ibrahim M, Karunaweera N, Kokwaro G, Koram KA, Lemnge M, Makani J, Marsh K, Michon P, Modiano D, Molyneux ME, Mueller I, Parker M, Peshu N, Plowe CV, Puijalon O, Reeder J, Reyburn H, Riley EM, Sakuntabhai A, Singhasivanon P, Sirima S, Tall A, Taylor TE, Thera M, Troye-Blomberg M, Williams TN, Wilson M, Kwiatkowski DP (2009) Genome-wide and fine-resolution association analysis of malaria in West Africa. Nat Genet 41(6):657-665. https://doi. org/10.1038/ng.388

Johnston HR, Hu YJ, Gao J, O'Connor TD, Abecasis GR, Wojcik GL, Gignoux CR, Gourraud PA, Lizee A, Hansen M, Genuario R, Bullis D, Lawley C, Kenny EE, Bustamante C, Beaty TH, Mathias RA, Barnes KC, Qin ZS (2017) Identifying tagging SNPs for African specific genetic variation from the African Diaspora Genome. Sci Rep 7:46398. https://doi.org/10.1038/ srep46398

Kariuki SN, Marin-Menendez A, Introini V, Ravenhill BJ, Lin Y-C, Macharia A, Makale J, Tendwa M, Nyamu W, Kotar J, Carrasquilla M, Rowe JA, Rockett K, Kwiatkowski D, Weekes MP, Cicuta P, Williams TN, Rayner JC (2018) Red blood cell tension controls Plasmodium falciparum invasion and protects against severe malaria in the Dantu blood group. bioRxiv. https://doi. org/10.1101/475442

Komba AN, Makani J, Sadarangani M, Ajala-Agbo T, Berkley JA, Newton CR, Marsh K, Williams TN (2009) Malaria as a cause of morbidity and mortality in children with homozygous sickle cell disease on the coast of Kenya. Clin Infect Dis 49(2):216-222. https://doi.org/10.1086/599834

Kwiatkowski DP (2005) How malaria has affected the human genome and what human genetics can teach us about malaria. Am J Hum Genet 77(2):171-192

Leffler EM, Band G, Busby GBJ, Kivinen K, Le QS, Clarke GM, Bojang KA, Conway DJ, Jallow M, Sisay-Joof F, Bougouma EC, Mangano VD, Modiano D, Sirima SB, Achidi E, Apinjoh TO, Marsh K, Ndila CM, Peshu N, Williams TN, Drakeley C, Manjurano A, Reyburn H, Riley E, Kachala D, Molyneux M, Nyirongo V, Taylor T, Thornton N, Tilley L, Grimsley S, Drury E, Stalker J, Cornelius V, Hubbart C, Jeffreys AE, Rowlands K, Rockett KA, Spencer CCA, Kwiatkowski DP, Network Malaria Genomic Epidemiology (2017) Resistance to malaria through structural variation of red blood cell invasion receptors. Science. https://doi.org/10.1126/science.aam6393

Leffler EM, Gao Z, Pfeifer S, Segurel L, Auton A, Venn O, Bowden R, Bontrop R, Wall JD, Sella G, Donnelly P, McVean G, Przeworski M (2013) Multiple instances of ancient balancing selection shared between humans and chimpanzees. Science 339(6127):1578-1582. https://doi.org/10.1126/science.1234070

Lelliott PM, McMorran BJ, Foote SJ, Burgio G (2015) The influence of host genetics on erythrocytes and malaria infection: is there therapeutic potential? Malar J 14:289. https://doi.org/10.1186/ s12936-015-0809-x

Lessard S, Gatof ES, Beaudoin M, Schupp PG, Sher F, Ali A, Prehar S, Kurita R, Nakamura Y, Baena E, Ledoux J, Oceandy D, Bauer DE, Lettre G (2017) An erythroid-specific ATP2B4 enhancer mediates red blood cell hydration and malaria susceptibility. J Clin Invest 127(8):3065-3074. https://doi.org/10.1172/jci94378

Lo E, Yewhalaw D, Zhong D, Zemene E, Degefa T, Tushune K, Ha M, Lee MC, James AA, Yan G (2015) Molecular epidemiology of Plasmodium vivax and Plasmodium falciparum malaria among 
Duffy-positive and Duffy-negative populations in Ethiopia. Malar J 14:84. https://doi.org/10.1186/s12936-015-0596-4

Luty AJ, Perkins DJ, Lell B, Schmidt-Ott R, Lehman LG, Luckner D, Greve B, Matousek P, Herbich K, Schmid D, Weinberg JB, Kremsner PG (2000) Low interleukin-12 activity in severe Plasmodium falciparum malaria. Infect Immun 68(7):3909-3915. https://doi.org/10.1128/iai.68.7.3909-3915.2000

Luzzatto L, Nwachuku-Jarrett ES, Reddy S (1970) Increased sickling of parasitised erythrocytes as mechanism of resistance against malaria in the sickle-cell trait. Lancet 1(7642):319-321

Luzzi GA, Merry AH, Newbold CI, Marsh K, Pasvol G, Weatherall DJ (1991a) Surface antigen expression on Plasmodium falciparum-infected erythrocytes is modified in alpha- and betathalassemia. J Exp Med 173(4):785-791. https://doi.org/10.1084/ jem.173.4.785

Luzzi GA, Merry AH, Newbold CI, Marsh K, Pasvol G (1991b) Protection by alpha-thalassaemia against Plasmodium falciparum malaria: modified surface antigen expression rather than impaired growth or cytoadherence. Immunol Lett 30(2):233-240

Mackey JP, Vivarelli F (1954) Sickle-cell anaemia. BMJ 1(4856):276276. https://doi.org/10.1136/bmj.1.4856.276

Mackinnon MJ, Gunawardena DM, Rajakaruna J, Weerasingha S, Mendis KN, Carter R (2000) Quantifying genetic and nongenetic contributions to malarial infection in a Sri Lankan population. Proc Natl Acad Sci USA 97(23):12661-12666

Mackinnon MJ, Mwangi TW, Snow RW, Marsh K, Williams TN (2005) Heritability of malaria in Africa. Plos Med 2(12):e340

Makani J, Komba AN, Cox SE, Oruo J, Mwamtemi K, Kitundu J, Magesa P, Rwezaula S, Meda E, Mgaya J, Pallangyo K, Okiro E, Muturi D, Newton CR, Fegan G, Marsh K, Williams TN (2010) Malaria in patients with sickle cell anemia: burden, risk factors, and outcome at the outpatient clinic and during hospitalization. Blood 115(2):215-220. https://doi.org/10.1182/blood-2009-07233528

Malaguarnera L, Imbesi RM, Pignatelli S, Simpore J, Malaguarnera M, Musumeci S (2002) Increased levels of interleukin-12 in Plasmodium falciparum malaria: correlation with the severity of disease. Parasite Immunol 24(7):387-389. https://doi.org/10. 1046/j.1365-3024.2002.00478.x

MalariaGEN MG, Network E (2014) Reappraisal of known malaria resistance loci in a large multicenter study. Nat Genet 46(11):1197-1204. https://doi.org/10.1038/ng.3107

MalariaGEN MG, Network E (2019) Insights into malaria susceptibility using genome-wide data on 17,000 individuals from Africa, Asia and Oceania. Nat Commun 10(1):5732. https://doi. org/10.1038/s41467-019-13480-z

Manolio TA, Collins FS, Cox NJ, Goldstein DB, Hindorff LA, Hunter DJ, McCarthy MI, Ramos EM, Cardon LR, Chakravarti A, Cho JH, Guttmacher AE, Kong A, Kruglyak L, Mardis E, Rotimi CN, Slatkin M, Valle D, Whittemore AS, Boehnke M, Clark AG, Eichler EE, Gibson G, Haines JL, Mackay TF, McCarroll SA, Visscher PM (2009) Finding the missing heritability of complex diseases. Nature 461(7265):747-753. https://doi.org/10.1038/ nature 08494

Martinsen ES, Perkins SL, Schall JJ (2008) A three-genome phylogeny of malaria parasites (Plasmodium and closely related genera): evolution of life-history traits and host switches. Mol Phylogenet Evol 47(1):261-273. https://doi.org/10.1016/j.ympev .2007.11.012

Mayer DC, Cofie J, Jiang L, Hartl DL, Tracy E, Kabat J, Mendoza LH, Miller LH (2009) Glycophorin B is the erythrocyte receptor of Plasmodium falciparum erythrocyte-binding ligand, EBL-1. Proc Natl Acad Sci USA 106(13):5348-5352. https://doi.org/10.1073/ pnas.0900878106

Mayer DC, Jiang L, Achur RN, Kakizaki I, Gowda DC, Miller LH (2006) The glycophorin C N-linked glycan is a critical component of the ligand for the Plasmodium falciparum erythrocyte receptor BAEBL. Proc Natl Acad Sci U S A 103(7):23582362. https://doi.org/10.1073/pnas.0510648103

Mayer DC, Kaneko O, Hudson-Taylor DE, Reid ME, Miller LH (2001) Characterization of a Plasmodium falciparum erythrocyte-binding protein paralogous to EBA-175. Proc Natl Acad Sci USA 98(9):5222-5227. https://doi.org/10.1073/pnas.081075398

Mayer DC, Mu JB, Feng X, Su XZ, Miller LH (2002) Polymorphism in a Plasmodium falciparum erythrocyte-binding ligand changes its receptor specificity. J Exp Med 196(11):1523-1528

Mayer DC, Mu JB, Kaneko O, Duan J, Su XZ, Miller LH (2004) Polymorphism in the Plasmodium falciparum erythrocyte-binding ligand JESEBL/EBA-181 alters its receptor specificity. Proc Natl Acad Sci USA 101(8):2518-2523

McAuley CF, Webb C, Makani J, Macharia A, Uyoga S, Opi DH, Ndila C, Ngatia A, John AG, Scott KM, Williams TN (2010) High mortality from Plasmodium falciparum malaria in children living with sickle cell anemia on the coast of Kenya. Blood 116(10):1663-1668. https://doi.org/10.1182/blood-2010-01265249

Menard D, Barnadas C, Bouchier C, Henry-Halldin C, Gray LR, Ratsimbasoa A, Thonier V, Carod JF, Domarle O, Colin Y, Bertrand O, Picot J, King CL, Grimberg BT, Mercereau-Puijalon $\mathrm{O}$, Zimmerman PA (2010) Plasmodium vivax clinical malaria is commonly observed in Duffy-negative Malagasy people. Proc Natl Acad Sci USA 107(13):5967-5971. https://doi.org/10.1073/ pnas.0912496107

Miller LH, Aikawa M, Johnson JG, Shiroishi T (1979) Interaction between cytochalasin B-treated malarial parasites and erythrocytes. Attachment and junction formation. J Exp Med 149(1):172-184

Miller LH, Mason SJ, Clyde DF, McGinniss MH (1976) The resistance factor to Plasmodium vivax in blacks. The Duffy-bloodgroup genotype, FyFy. N Engl J Med 295(6):302-304. https:// doi.org/10.1056/nejm197608052950602

Miller LH, Mason SJ, Dvorak JA, McGinniss MH, Rothman IK (1975) Erythrocyte receptors for (Plasmodium knowlesi) malaria: Duffy blood group determinants. Science 189(4202):561-563

Miller MJ, Neel JV, Livingstone FB (1956) Distribution of parasites in the red cells of sickle-cell trait carriers infected with Plasmodium falciparum. Trans R Soc Trop Med Hyg 50(3):294-296

Mueller I, Shakri AR, Chitnis CE (2015) Development of vaccines for Plasmodium vivax malaria. Vaccine 33(52):7489-7495. https:// doi.org/10.1016/j.vaccine.2015.09.060

Munde EO, Raballah E, Okeyo WA, Ong'echa JM, Perkins DJ, Ouma C (2017) Haplotype of non-synonymous mutations within IL-23R is associated with susceptibility to severe malaria anemia in a $P$. falciparum holoendemic transmission area of Kenya. BMC Infect Dis 17(1):291. https://doi.org/10.1186/s12879-017-2404-y

Ndila CM, Uyoga S, Macharia AW, Nyutu G, Peshu N, Ojal J, Shebe M, Awuondo KO, Mturi N, Tsofa B, Sepulveda N, Clark TG, Band G, Clarke G, Rowlands K, Hubbart C, Jeffreys A, Kariuki S, Marsh K, Mackinnon M, Maitland K, Kwiatkowski DP, Rockett KA, Williams TN (2018) Human candidate gene polymorphisms and risk of severe malaria in children in Kilifi, Kenya: a case-control association study. Lancet Haematol. https://doi. org/10.1016/s2352-3026(18)30107-8

Ngassa Mbenda HG, Das A (2014) Molecular evidence of Plasmodium vivax mono and mixed malaria parasite infections in Duffy-negative native Cameroonians. PLoS One 9(8):e103262. https://doi. org/10.1371/journal.pone.0103262

Niangaly A, Karthigayan G, Amed O, Coulibaly D, Sa JM, Adams M, Travassos MA, Ferrero J, Laurens MB, Kone AK, Thera MA, Plowe CV, Miller LH, Doumbo OK (2017) Plasmodium vivax infections over 3 years in Duffy blood group negative Malians 
in Bandiagara Mali. Am J Trop Med Hyg 97(3):744-752. https ://doi.org/10.4269/ajtmh.17-0254

Ong'echa JM, Remo AM, Kristoff J, Hittner JB, Were T, Ouma C, Otieno RO, Vulule JM, Keller CC, Awandare GA, Perkins DJ (2008) Increased circulating interleukin (IL)-23 in children with malarial anemia: in vivo and in vitro relationship with co-regulatory cytokines IL-12 and IL-10. Clin Immunol 126(2):211-221. https://doi.org/10.1016/j.clim.2007.08.007

Opi DH, Ochola LB, Tendwa M, Siddondo BR, Ocholla H, Fanjo H, Ghumra A, Ferguson DJ, Rowe JA, Williams TN (2014) Mechanistic studies of the negative epistatic malaria-protective interaction between sickle cell trait and alpha+thalassemia. EBioMedicine 1(1):29-36. https://doi.org/10.1016/j.ebiom.2014.10.006

Opi DH, Swann O, Macharia A, Uyoga S, Band G, Ndila CM, Harrison EM, Thera MA, Kone AK, Diallo DA, Doumbo OK, Lyke KE, Plowe CV, Moulds JM, Shebbe M, Mturi N, Peshu N, Maitland K, Raza A, Kwiatkowski DP, Rockett KA, Williams TN, Rowe JA (2018) Two complement receptor one alleles have opposing associations with cerebral malaria and interact with alpha(+) thalassaemia. Elife. https://doi.org/10.7554/eLife.31579

Pasvol G (1980) The interaction between sickle haemoglobin and the malarial parasite Plasmodium falciparum. Trans R Soc Trop Med Hyg 74(6):701-705

Pasvol G, Weatherall DJ, Wilson RJ (1978) Cellular mechanism for the protective effect of haemoglobin $\mathrm{S}$ against $P$. falciparum malaria. Nature 274(5672):701-703

Phimpraphi W, Paul R, Witoonpanich B, Turbpaiboon C, Peerapittayamongkol C, Louicharoen C, Casademont I, Tungpradabkul S, Krudsood S, Kaewkunwal J, Sura T, Looareesuwan S, Singhasivanon P, Sakuntabhai A (2008) Heritability of P. falciparum and $P$. vivax malaria in a Karen population in Thailand. PLoS One 3(12): 3887

Pogo AO, Chaudhuri A (1995) Duffy and receptors for $P$. vivax and chemotactic peptides. Transfus Clin Biol 2(4):269-276

Ravenhall M, Campino S, Sepulveda N, Manjurano A, Nadjm B, Mtove G, Wangai H, Maxwell C, Olomi R, Reyburn H, Drakeley CJ, Riley EM, Clark TG (2018) Novel genetic polymorphisms associated with severe malaria and under selective pressure in North-eastern Tanzania. PLoS Genet 14(1):e1007172. https:// doi.org/10.1371/journal.pgen.1007172

Rihet P, Traore Y, Abel L, Aucan C, Traore-Leroux T, Fumoux F (1998) Malaria in humans: Plasmodium falciparum blood infection levels are linked to chromosome 5q31-q33. Am J Hum Genet 63(2):498-505. https://doi.org/10.1086/301967

Rogier C, Tall A, Diagne N, Fontenille D, Spiegel A, Trape JF (1999) Plasmodium falciparum clinical malaria: lessons from longitudinal studies in Senegal. Parassitologia 41(1-3):255-259

Rowe A, Obeiro J, Newbold CI, Marsh K (1995) Plasmodium falciparum rosetting is associated with malaria severity in Kenya. Infect Immun 63(6):2323-2326

Rowe JA, Claessens A, Corrigan RA, Arman M (2009) Adhesion of Plasmodium falciparum-infected erythrocytes to human cells: molecular mechanisms and therapeutic implications. Expert Rev Mol Med 11:e16. https://doi.org/10.1017/S1462399409001082

Rowe JA, Handel IG, Thera MA, Deans AM, Lyke KE, Kone A, Diallo DA, Raza A, Kai O, Marsh K, Plowe CV, Doumbo OK, Moulds JM (2007) Blood group O protects against severe Plasmodium falciparum malaria through the mechanism of reduced rosetting. Proc Natl Acad Sci USA 104(44):17471-17476. https:// doi.org/10.1073/pnas.0705390104

Rowe JA, Moulds JM, Newbold CI, Miller LH (1997) P. falciparum rosetting mediated by a parasite-variant erythrocyte membrane protein and complement-receptor 1. Nature 388(6639):292-295. https://doi.org/10.1038/40888

Ruwende C, Khoo SC, Snow RW, Yates SN, Kwiatkowski D, Gupta S, Warn P, Allsopp CE, Gilbert SC, Peschu N et al (1995) Natural selection of hemi- and heterozygotes for G6PD deficiency in Africa by resistance to severe malaria. Nature 376(6537):246249. https://doi.org/10.1038/376246a0

Ryan JR, Stoute JA, Amon J, Dunton RF, Mtalib R, Koros J, Owour B, Luckhart S, Wirtz RA, Barnwell JW, Rosenberg R (2006) Evidence for transmission of Plasmodium vivax among a Duffy antigen negative population in Western Kenya. Am J Trop Med Hyg 75(4):575-581

Sakuntabhai A, Ndiaye R, Casademont I, Peerapittayamongkol C, Rogier C, Tortevoye P, Tall A, Paul R, Turbpaiboon C, Phimpraphi W, Trape JF, Spiegel A, Heath S, Mercereau-Puijalon O, Dieye A, Julier C (2008) Genetic determination and linkage mapping of Plasmodium falciparum malaria related traits in Senegal. PLoS One 3(4):e2000. https://doi.org/10.1371/journ al.pone. 0002000

Schellenberg JR, Smith T, Alonso PL, Hayes RJ (1994) What is clinical malaria? Finding case definitions for field research in highly endemic areas. Parasitol Today 10(11):439-442. https://doi. org/10.1016/0169-4758(94)90179-1

Sim BK, Chitnis CE, Wasniowska K, Hadley TJ, Miller LH (1994) Receptor and ligand domains for invasion of erythrocytes by Plasmodium falciparum. Science 264(5167):1941-1944

Singh B, Kim Sung L, Matusop A, Radhakrishnan A, Shamsul SS, Cox-Singh J, Thomas A, Conway DJ (2004) A large focus of naturally acquired Plasmodium knowlesi infections in human beings. Lancet 363(9414):1017-1024. https://doi.org/10.1016/ s0140-6736(04)15836-4

Snow RW, Guerra CA, Noor AM, Myint HY, Hay SI (2005) The global distribution of clinical episodes of Plasmodium falciparum malaria. Nature 434(7030):214-217

Teo YY, Small KS, Kwiatkowski DP (2010) Methodological challenges of genome-wide association analysis in Africa. Nat Rev Genet 11(2):149-160. https://doi.org/10.1038/nrg2731

Tiffert T, Lew VL, Ginsburg H, Krugliak M, Croisille L, Mohandas N (2005) The hydration state of human red blood cells and their susceptibility to invasion by Plasmodium falciparum. Blood 105(12):4853-4860

Timmann C, Evans JA, König IR, Kleensang A, Rüschendorf F, Lenzen J, Sievertsen J, Becker C, Enuameh Y, Kwakye KO, Opoku E, Browne EN, Ziegler A, Nürnberg P, Horstmann RD (2007) Genome-wide linkage analysis of malaria infection intensity and mild disease. PLoS Genet 3(3):e48

Timmann C, Thye T, Vens M, Evans J, May J, Ehmen C, Sievertsen J, Muntau B, Ruge G, Loag W, Ansong D, Antwi S, Asafo-Adjei E, Nguah SB, Kwakye KO, Akoto AO, Sylverken J, Brendel M, Schuldt K, Loley C, Franke A, Meyer CG, Agbenyega T, Ziegler A, Horstmann RD (2012) Genome-wide association study indicates two novel resistance loci for severe malaria. Nature 489(7416):443-446. https://doi.org/10.1038/nature11334

Tishkoff SA, Reed FA, Friedlaender FR, Ehret C, Ranciaro A, Froment A, Hirbo JB, Awomoyi AA, Bodo JM, Doumbo O, Ibrahim M, Juma AT, Kotze MJ, Lema G, Moore JH, Mortensen H, Nyambo TB, Omar SA, Powell K, Pretorius GS, Smith MW, Thera MA, Wambebe C, Weber JL, Williams SM (2009) The genetic structure and history of Africans and African Americans. Science 324(5930):1035-1044. https://doi.org/10.1126/science.1172257

Tishkoff SA, Williams SM (2002) Genetic analysis of African populations: human evolution and complex disease. Nat Rev Genet 3(8):611-621. https://doi.org/10.1038/nrg865

Tolia NH, Enemark EJ, Sim BK, Joshua-Tor L (2005) Structural basis for the EBA-175 erythrocyte invasion pathway of the malaria parasite Plasmodium falciparum. Cell 122(2):183-193. https:// doi.org/10.1016/j.cell.2005.05.033

Udomsangpetch R, Todd J, Carlson J, Greenwood BM (1993) The effects of hemoglobin genotype and ABO blood group on the formation of rosettes by Plasmodium falciparum-infected red 
blood cells. Am J Trop Med Hyg 48(2):149-153. https://doi. org/10.4269/ajtmh.1993.48.149

Verra F, Mangano VD, Modiano D (2009) Genetics of susceptibility to Plasmodium falciparum: from classical malaria resistance genes towards genome-wide association studies. Parasite Immunol 31(5):234-253. https://doi.org/10.1111/j.1365-3024.2009.01106 . $\mathrm{x}$

Wambua S, Mwangi TW, Kortok M, Uyoga SM, Macharia AW, Mwacharo JK, Weatherall DJ, Snow RW, Marsh K, Williams TN (2006) The effect of alpha+-thalassaemia on the incidence of malaria and other diseases in children living on the coast of Kenya. PLoS Med 3(5):e158. https://doi.org/10.1371/journ al.pmed.0030158

Wertheimer SP, Barnwell JW (1989) Plasmodium vivax interaction with the human Duffy blood group glycoprotein: identification of a parasite receptor-like protein. Exp Parasitol 69(4):340-350

WHO, World Health Organization. 2019. World Malaria Report.

Williams TN (2016) Host genetics. In: Chitnis CE, Chauhan VS, Gaur D Advances in malaria research

Williams TN, Mwangi TW, Roberts DJ, Alexander ND, Weatherall DJ, Wambua S, Kortok M, Snow RW, Marsh K (2005) An immune basis for malaria protection by the sickle cell trait. PLoS Med 2(5):e128. https://doi.org/10.1371/journal.pmed.0020128

Williams TN, Weatherall DJ, Newbold CI (2002) The membrane characteristics of Plasmodium falciparum-infected and -uninfected heterozygous alpha(0)thalassaemic erythrocytes. Br J Haematol 118(2):663-670
Yuthavong Y, Bunyaratvej A, Kamchonwongpaisan S (1990) Increased susceptibility of malaria-infected variant erythrocytes to the mononuclear phagocyte system. Blood Cells 16(2-3):591-597

Yuthavong Y, Butthep P, Bunyaratvej A, Fucharoen S, Khusmith S (1988) Impaired parasite growth and increased susceptibility to phagocytosis of Plasmodium falciparum infected alpha-thalassemia or hemoglobin Constant Spring red blood cells. Am J Clin Pathol 89(4):521-525. https://doi.org/10.1093/ajcp/89.4.521

Zambo B, Varady G, Padanyi R, Szabo E, Nemeth A, Lango T, Enyedi A, Sarkadi B (2017) Decreased calcium pump expression in human erythrocytes is connected to a minor haplotype in the ATP2B4 gene. Cell Calcium 65:73-79. https://doi.org/10.1016/j. ceca.2017.02.001

Zhang L, Prather D, Vanden Eng J, Crawford S, Kariuki S, ter Kuile F, Terlouw D, Nahlen B, Lal AA, Slutsker L, Udhayakumar V, Shi YP (2010) Polymorphisms in genes of interleukin 12 and its receptors and their association with protection against severe malarial anaemia in children in western Kenya. Malar J 9:87. https://doi.org/10.1186/1475-2875-9-87

Publisher's Note Springer Nature remains neutral with regard to jurisdictional claims in published maps and institutional affiliations. 